\title{
IMPACT OF INSTITUTIONAL DISTRIBUTION ON TRAFFIC CONGESTION: A STATISTICAL STUDY OF TRAFFIC CONGESTION IN SHILLONG CITY
}

\author{
Gitumoni Rajbongshi ${ }^{1}$ \\ ${ }^{1}$ Shillong Commerce College, Meghalaya, India \\ Received 27 June 2020; accepted 26 July 2020
}

\begin{abstract}
This paper tried to analyse a fresh approach to traffic congestion analysis. In this research an attempt has been made to highlight one of the important impacts which could significantly affect traffic congestion problem in the study area i.e., Shillong. Traffic congestion scenario of the city has been interpreted through analysis of spatio-temporal analysis of vehicles. Thereafter, to analyze the locational impact of traffic congestion in the city, the number of major institutions (official, educational, banks, church, etc.) located near the study points (Mawlai, Garikhana, Dhankheti, Police Bazaar and Nongthymmai) within one sq km around them has been collected. Thereafter, Chi-square test has been used to determine whether there is significant difference in the distribution of institutions within the city. Results showed that locational misdistribution of government offices and institutions across these chosen points causes variation in occurrence of traffic flow and hence leading to congestion.
\end{abstract}

Keywords: traffic congestion, spatio-temporal analysis, institutional distribution, Chi-sq test, prevention of traffic congestion, policy implications.

\section{Introduction}

Over the years, the city Shillong have observed unbalanced growth of transport system and means of transport across the cities and rural areas in any country. Cities and traffic have developed hand in hand since the earliest large human settlements. However, the population growth in the urban centres for various socio-economic reasons and their habit towards luxuries in the form of having individual vehicles (single or multiple) have led to the disproportionate growth of road communications and overall number of vehicles. Though vehicle growth continues with rising affluence of people, roads have not been expanded in the desired proportion due to scarcity of appropriate land space, most of which have already been preoccupied by the settled inhabitants or non-usable for the peculiar texture. The expansion is further constrained due to the hill slopes and narrow strips available in hill towns like Shillong that involves huge cost of construction, which is uneconomic and very difficult to manage. The same forces that drive inhabitants to occupy large urban areas thus lead to intolerable levels of traffic congestion. Many a time, having more cars and putting them on the road instead of helping better communication, it blocks peoples' movement at the time of urgent

${ }^{1}$ Corresponding author: gitumani.rajbongshi@scccollege.ac.in 
need. Even sometimes the commuters feel walking is better than travelling by car during the peak hours of the day in a congested city road. Thus, controlling of road traffic congestion particularly in the urban centres, and more so, in a hill town has become a menace and the problem compounded faster than water and air traffic issues. Though construction of underpasses, metro railways, and flyovers has solved the problem partially in many big cities; in hill towns like Shillong all these arrangements are far from reality. Prevailing hill terrains preclude use of such techniques and wherever possible for exorbitant cost is not undertaken. It therefore calls for stringent traffic control mechanism to have some relief to the town population. Thus, this paper aimed at analysing the nature of traffic congestion in Shillong city and test whether improper distribution of government offices and institutions leads to traffic congestion.

\section{Review of Literature}

Traffic congestion has become almost a daily affair of urban population across the countries. The issue is related mostly to the urban transport affecting movement of people towards various destinations in their daily or occasional activities. Since, it is connected with the welfare of people through extension of travel time and thereby delaying the works. Whether merely a meeting or business activities or reaching of people to academic institutions or patients to hospital; it has been recognised by the academicians, researchers, engineers and policy makers in order to find out solution to such growing menace faced by urban people increasingly over the years. A number of studies have already been undertaken at various levels to analyse various aspects of traffic congestion like engineering problems, structural and geographical issues, socio-economic impacts etc across the world (Khan and Islam, 2013; Olawale et al., 2015; Raheem et al., 2015).

A number of studies have been undertaken to understand the issues related to the social cost imposed due to traffic congestion. According to Uddin (2009) traffic congestion is highly associated with the rapid growth of passenger vehicles on account of rising income and the development of low-cost cars into the market. Ukpata and Etika (2012) also tried to find out the causes of traffic congestion in Nigeria and to offer possible remedies to the problem. The results showed that poor driving habits, poor road networks, inadequate road capacity and lack of parking facilities constitute the greatest cause of traffic congestion.

Further, faulty traffic signalling systems, inadequate manpower, narrow road spaces, overtaking tendency of drivers, traffic rule violation, lack of road planning of city road, rickshaw, etc. were found to be some of the reasons of traffic congestion in Dhaka city (Mahmud et al., 2012). Here, various causes of traffic congestion were identified by using group discussion. Through structured questionnaire they tried to find out various impacts of traffic congestion on population like wastage of time, economic loss and so on. Results showed that people lose about 55 percent of their time daily due to the problem of traffic jam in Dhaka city, Bangladesh. They also found traffic rule violation as another reason compounding traffic congestion and the congestion caused deteriorating ambient air quality with excessive harmful pollutants like $\mathrm{SO}_{\mathrm{X}}, \mathrm{NO}_{\mathrm{X}}, \mathrm{CO}_{\mathrm{X}}$, nd SPM. Some of their suggestions were development of infrastructure, removing rickshaw, strict traffic law management, rescheduling of office/school time, etc. 
He (2012) identified journey delays, time wasted, business loss, reduction in the quality of life, etc., as the negative effects of traffic congestion. The author discussed in traffic congestion in detail and cited examples of Dalian, China where ETSS was used to help them in road traffic management. He identified 5CW problems of traffic congestion to better understand road traffic management, like when happened, where, how, why and what change.

Ye (2012) identified longer travel time, increase in energy consumption, environmental pollution and traffic accidents as the impacts of traffic congestion. In order to estimate the price of traffic congestion, factors like vehicle types, congestion degree, road network situation and travellers bearing ability were considered. They opined that development of scientific plan, strong support of the public, development of public transport could be helpful in solving the problem of traffic congestion.

Poor road traffic management, lack of adequate town planning, lack of space for expansion of road infrastructure were also identified as the reasons for traffic congestion in the developing nations in the studies of Jain et al. (2012) and Chama (2013). To detect the traffic congestion in the critical areas they used a simple image processing algorithm to analyze CCTV video feeds from traffic cameras. With the help of this algorithm they tried to show evidence of actual congestion in Sao Paulo, Brazil and Nairobi in Kenya respectively. The reasons for traffic congestion as identified include unplanned cities, poor discipline of drivers, alternate traffic means, tighter budget, etc. Study revealed that peak hour's congestion in Brazil was from 4:30 P.M. to 8:30 P.M. whereas in Kenya busy hours were from 10 A.M. to 2 P.M.

Review of above mentioned literatures reveal that land use factors, physical factors, human factors and technical factors as the factors responsible for traffic congestion. But there is hardly any study which statistically tried to test if improper locations of institutions lead to traffic congestion. Thus, this paper tried to test with the use of Chi-square test the impact of locational distribution in road congestion.

\section{Data and Methodology}

Primary data have been collected by using the following tools: traffic volume count and questionnaire. Traffic volume count enable us to know spatial and temporal distribution of traffic flow in the town that would further help to design schemes for improvement of roads and thus would help to allocate the scare economic resources most advantageously.

Structured questionnaires have been distributed randomly among road users which include private car owners, taxi drivers, and businessmen (Other than commercial taxi owners or drivers). Private car owners are those respondents who travel with private car, under this category includes, government servants, employers in private offices and institutions, teachers and students. Under the category of taxi drivers includes local and tourists taxi drivers. Under the third category i.e., businessmen include those respondents who are into business activities. Of total 600 questionnaires, each category has been distributed 200 each in the following order: 
1. Private individuals using their own vehicles (200);

2. Taxi drivers: Local and Tourist (200);

3. Businessman (200).

For the assessment of traffic congestion, the first step is the selection of zones or road intersections. Thereafter, the sample respondents were selected. Since the vehicles were mobile, it was not possible to have direct interview on the spot (by stopping cars on the road would have created anarchy in the traffic movement and there is no much space to stop on the side and do it). Therefore, only the contacts of the respondents were collected at random in different time intervals as counting of vehicles were done and then interview schedules were used at a later stage and filled through direct interview in convenient locations chosen by the respective respondents.

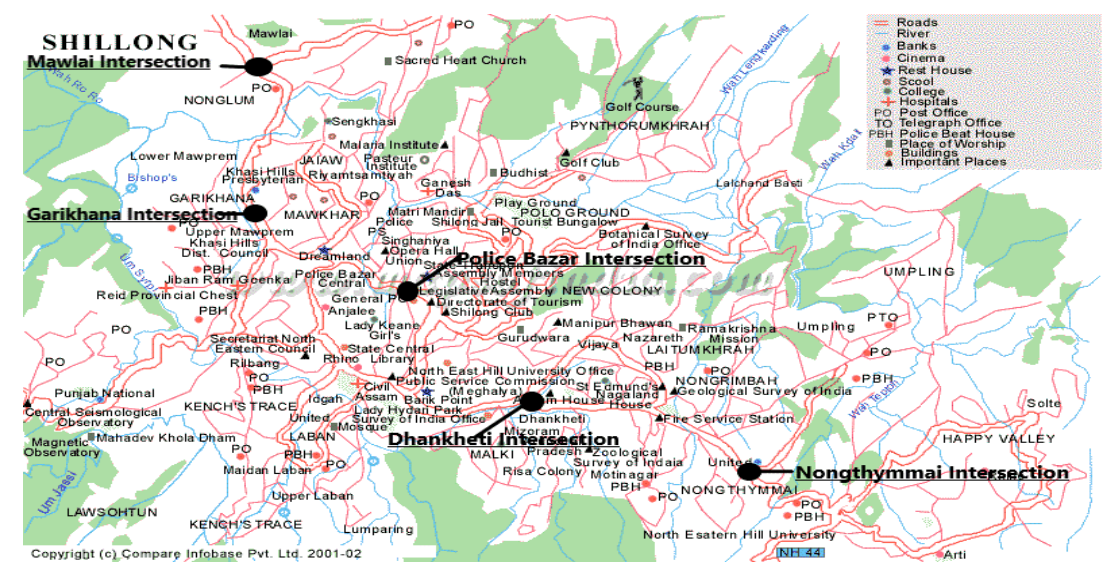

Fig. 1.

Location of the Surveyed Intersections in Shillong City

Source: (Mappery, 2019)

Respondents were asked to rank in order 5 major road intersections with traffic flow and congestion in Shillong and those five major intersections have been chosen based on their ranking from top in the frequency distribution table. Out of the 16 major road intersections in the city, top 5 major intersections namely Mawlai point, Garikhana, Police Bazar intersection, Dhankheti intersection and Nongthymmai intersection are chosen for the present study (Appendix 1). Also, these points are located in various places covering the major portion of the city and also on the National Highway that passes through the town (Fig. 1). Also, these intersections observe multiple traffic varieties at different time intervals of the day. Mawlai, Garikhana and Police Bazar records office, educational institute and market visitors with more concentration of business traffic, while the other two records major educational institute visitors along with other domestic and commercial traffic.

At the above mentioned five locations, manual vehicle traffic count has been made and vehicle count has been conducted for 12 hours in a day from 7:00 A.M. to 7:00 
P.M. with the use of pen and paper method, taking 15 minutes internal. The counts have been conducted for three months (July 2019 to September 2019). Average of the three months data have been taken for the spatiotemporal analysis of traffic congestion in the city. Before morning 7.00 A. M. usually there is no traffic congestion and after 7.00 P. M. in the evening also traffic congestion does not occur excepting some special occasions.

For analysing the impact of locational distribution on traffic congestion, number of institutions surrounding the study locations has been counted. Thereafter, Chi- square test has been employed to test the alternative hypothesis that locational misdistribution of institutions leads to traffic congestion in the Shillong city. Thereafter, measures to solve the problem of traffic congestion have also been analysed. Respondents have been asked to reveal a number of valuable suggestions which is analysed by assigning codes to each of the suggestions.

\section{Analysis and Results}

\subsection{Spatio- Temporal Analysis of Traffic Congestion in Shillong City}

For analysing spatio-temporal variation in movement of vehicles within the city, manual traffic volume counts have been conducted in major five locations in the city. The counts have been conducted for 12 hours duration (7.00 A.M. to 7.00 P.M.).

The graphical presentation of the average of the traffic volume count has been presented in Fig 2. It is revealed that traffic flow characteristics of zones surrounded by educational offices and institutions are more or less identical.

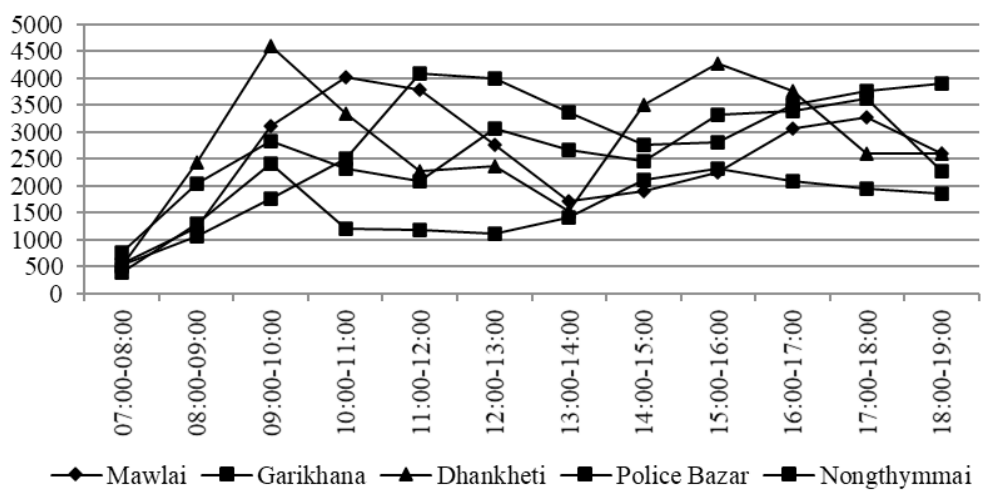

Fig. 2.

Average Traffic Flow Data of Mawlai, Garikhana, Dhankheti, Police Bazar and Nongthymmai from 7:00 AM to 7:00 PM (Number)

The highest level of congestion is observed in the Dhankheti junction point, especially from 8.00 A.M. to 9.00 A.M. and then again it reaches a peak around 3.00 P.M. This junction caters to the flow of traffic for the major educational institutions located in the surrounding. This point is also located at the heart of the city and it links many other alternative routes to various locations. Thus, most of those commuters have to pass 
through this intersection and face congestion at major part of the day. Apart from local taxis and cars; tourists' vehicles are also observed to pass in greater number through both the Mawlai and Dhankheti points and thus the points remain congested more during office and school hours (10:00 A.M. to 11:00 A.M. and 5:00 P.M. to 6:00 P.M.) (Fig 2).

Through the Mawlai junction also a crossing is there for the entry to North Eastern Hill University (NEHU), Shillong Campus, and Umshing area and thereby Institute buses cross that junction during most of the time of the day along with other public transportation buses. It is $2.5 \mathrm{~km}$ away from Garikhana junction and its traffic flow depends on the traffic flow in Garikhana. If there is traffic jam in Garikhana, its effect spreads to other road stretches connecting Garikhana, thereby affect Mawlai intersection.

Similar traffic behaviour is also observed in Garikhana and Nongthymmai but with less intensity. Peak hour traffic in Garikhana has been witnessed in the morning office hours from 9:00 A.M. to 10:00 A.M., and again around 12.00 Noon due to heavy business activity. During evening hours, it is observed to be congested from 5:00 P.M. to 6:00 P.M. It is one of the main points of vehicle stoppage as it is very near to the commercial market Barabazar that is extended to Police Bazaar. Many loadings and unloading of luggage take place in Garikhana since the sumo and bus stands are located just in the intersection (Fig 2).

The Police Bazar point is the centre of not only official institutions but also hub of commercial activities, so traffic flows here has been found to increase after 9.00 A.M. and reaches its peak during 11:00 A.M. to
12:00 Noon and after a lean patches traffic volume grows after 4:00 P.M. till 7:00 P.M. due to increasing business activities, and flow of office people who moves there after their offices are closed for the day and sometimes the congestion continues beyond 7.00 P.M. for a while.

Thus, the spatio-temporal analysis of traffic congestion reflects that traffic is highest in Dhankheti intersection and traffic is found to be more during school and office opening and closing timings. This however provides a meaningful insight that locations of institutions however have a significant impact on the traffic flow.

\subsection{Impact of Misdistribution of Government Offices and Educational Institutions on Traffic Congestion in the Town}

An attempt has been made to examine the impact of misdistribution of various institutions on traffic congestion by using a Chi-square test, on the information obtained from the opinion of the respondents (Gupta, 2000). To analyze the locational impact of traffic congestion in the city, the number of major institutions (official, educational, banks, church, etc) located near the study points (Mawlai, Garikhana, Dhankheti, Police Bazaar and Nongthymmai) within one sq $\mathrm{km}$ around them have been collected. Thereafter, Chi-square test has been used to determine whether there is significant difference in the distribution of institutions within the city.

In Table 1, whether there is significant unequal distribution of institution around one square KM of each intersection, which would be considered as the prime reasons for unequal movement of vehicles at odd times 
has been tested. One may argue about the heterogeneity of the institution and variation in size of employment in institution, which may go opposite to the number. But for the sake of convenience, here size of employment, students etc and thus overall traffic is considered to be proportional to the number of institutions in each intersection.

\section{Table 1}

Chi-Square Test for Inequality in Distribution of Institution

\begin{tabular}{|c|c|c|c|c|c|c|c|c|}
\hline Locations & Observed & Expected & $\begin{array}{l}\text { Observed - } \\
\text { Expected }\end{array}$ & $\begin{array}{l}\text { (Observed - } \\
\text { Expected)^2 }\end{array}$ & $\begin{array}{c}\text { (Observed - } \\
\text { Expected)^2/ } \\
\text { Expected Value }\end{array}$ & Df & $\begin{array}{c}\text { Critical } \\
\chi^{2} \\
\end{array}$ & $\begin{array}{c}\text { Calculated } \\
\chi^{2}\end{array}$ \\
\hline Mawlai & 10 & 20.8 & -10.8 & 116.64 & 5.61 & \multirow{5}{*}{4} & \multirow{5}{*}{9.48} & \multirow{5}{*}{37.02} \\
\hline Garikhana & 15 & 20.8 & -5.8 & 33.64 & 1.62 & & & \\
\hline Dhankheti & 44 & 20.8 & 23.2 & 538.24 & 25.88 & & & \\
\hline Police Bazar & 15 & 20.8 & -5.8 & 33.64 & 1.62 & & & \\
\hline Nongthymmai & 20 & 20.8 & -0.8 & 0.64 & 0.031 & & & \\
\hline Total & 104 & 104 & & & & & & \\
\hline Chi-Square & & & & & 37.02 & & & \\
\hline
\end{tabular}

Source: Calculated by the author using the primary data collected.

Results in Table 1 shows that the calculated value $\mathrm{Chi}-\mathrm{Sq}$ is greater than the critical value in all cases. Thus, it can be safely argued that locational misdistribution of government offices and institutions across these chosen points causes variation in occurrence of traffic flow and hence congestion. Due to this reason, traffic congestion is the highest in Dhankheti intersection as the number of institutions around this location is higher than that of any other chosen locations considered in this study (about 45 institutions). Details of the number of major institutions near the study locations have been presented in Table 2 .

Table 2

Name of the Institutions near the Study Locations (Mawlai, Garikhana, Dhankheti, Police Bazaar and Nongthymmai)

\begin{tabular}{|c|c|}
\hline Sl. No. & Name of the Institutions \\
\hline \multicolumn{2}{|c|}{ Institutions Nearby Mawlai Intersections } \\
\hline 1 & Mawlai Presbyterian College \\
\hline 2 & Sacred Heart Boys Higher Secondary School \\
\hline 3 & Spring of Life School \\
\hline 4 & SKC School \\
\hline 5 & JingkiengKsiar UP School \\
\hline 6 & Department of Health and Family Welfare \\
\hline 7 & Nongwar Basic School \\
\hline 8 & Mawlai Presbyterian HS School \\
\hline 9 & Greater Mawlai College \\
\hline 10 & Mayqueen School \\
\hline \multicolumn{2}{|r|}{ Institutions Nearby Garikhana Intersections } \\
\hline 1 & Buddha BhanuSaraswati College \\
\hline 2 & Khasi Hills Autonomous District Council \\
\hline 3 & Lumdiengjri Police Station \\
\hline 4 & Gorkha School \\
\hline 5 & Arya School \\
\hline 6 & Little Angels School \\
\hline 7 & Jhalupara Community Hall \\
\hline
\end{tabular}




\begin{tabular}{|c|c|}
\hline Sl. No. & Name of the Institutions \\
\hline 8 & Mohammadia- Al-Hussaine Masjid \\
\hline 9 & Directorate of Animal Husbandry \& Veterinary \\
\hline 10 & Mawprem Presbyterian Church \\
\hline 11 & Shillong Cooperative Apex Bank \\
\hline 12 & Shillong Cooperative Urban Bank \\
\hline 13 & Meghalaya Cooperative Apex Bank \\
\hline 14 & ICICI Bank \\
\hline 15 & Church of God \\
\hline \multicolumn{2}{|r|}{ Institutions Nearby Dhankheti Intersections } \\
\hline 1 & I L \& FS Institute of Skills \\
\hline 2 & HDB Financial Services Shillong \\
\hline 3 & SIDBI \\
\hline 4 & Rajeevv Gandhi Training Centre \\
\hline 5 & Shillong Law College \\
\hline 6 & ICFAI University Shillong Campus \\
\hline 7 & Fiduciary Services \\
\hline 8 & Ferdy School of Marital Arts \\
\hline 9 & Society for Indian Technical Institute \\
\hline 10 & Indian Institute of Professional Studies \\
\hline 11 & Asthetica Dental Academy \\
\hline 12 & Kelian Memory Secondary School \\
\hline 13 & Kelian Memory School \\
\hline 14 & Vivekanada Coaching Centre \\
\hline 15 & Ascend Coaching Centre \\
\hline 16 & St. Peter's School \\
\hline 17 & Moreau Institude of Integral Teaching \\
\hline 18 & Fermions Coaching Centre \\
\hline 19 & Malki Assamese LP School \\
\hline 20 & Spring Field School \\
\hline 21 & Bissau College \\
\hline 22 & Loreto Convent \\
\hline 23 & Stonyland Primary School \\
\hline 24 & ALS IAS Coaching Centre \\
\hline 25 & St. Edmund's College \\
\hline 26 & ShishuVidyalaya English UP School \\
\hline 27 & Cathredal of Marry Help of Christians \\
\hline 28 & Don Bosco Private ITI \\
\hline 29 & Don Bosco Technical School Shillong \\
\hline 30 & St. Anthony's Higher Secondary School \\
\hline 31 & St. Anthony's LP School \\
\hline 32 & Directorate of Economics and Statistics \\
\hline 33 & Chief Engineer Public Health Engineering \\
\hline 34 & Directorate of Social Welfare \\
\hline 35 & Directorate of Agriculture \\
\hline 36 & Holy Cross Fathers Brookdane \\
\hline 37 & Meghalaya Rural Development Society \\
\hline 38 & Aerodene Cottage \\
\hline 39 & Assam House \\
\hline 40 & Mizoram House \\
\hline 41 & Summit Quest House \\
\hline 42 & LIC Branch Office \\
\hline 43 & NABARD Bank \\
\hline 44 & Peak Petrol Pump \\
\hline 45 & Dhankheti Primary School \\
\hline \multicolumn{2}{|r|}{ Institutions Nearby Police Bazaar Intersections } \\
\hline 1 & R B Anup Chand Hindi Secondary School \\
\hline 2 & Lady Keane School \\
\hline 3 & Lady Keane College \\
\hline
\end{tabular}




\begin{tabular}{|c|c|}
\hline Sl. No. & Name of the Institutions \\
\hline 4 & Islamia Secondary School \\
\hline 5 & Blika Hills Vidyalaya Secondary School \\
\hline 6 & New High Court \\
\hline 7 & Old High Court \\
\hline 8 & Meghalaya Legislative Assembly \\
\hline 9 & Shillong General Post office \\
\hline 10 & Office of Deputy Commissioner \\
\hline 11 & Shillong Club \\
\hline 12 & RKM Cultural Institute \\
\hline 13 & Vishal Mega Mart \\
\hline 14 & Assam Oil \\
\hline 15 & Government Girls Higher Secondary School \\
\hline \multicolumn{2}{|r|}{ Institutions Nearby Nongthymmai Intersections } \\
\hline 1 & Indian Institute of Management Shillong \\
\hline 2 & Shillong School of Music \\
\hline 3 & Morning Star College \\
\hline 4 & St. Dominic College \\
\hline 5 & Alpine College \\
\hline 6 & St. Xavier School \\
\hline 7 & National Institute of Fashion Technology \\
\hline 8 & St. John's School Whitehall \\
\hline 9 & Mrs. N Hills Tiny Tots Nursery \\
\hline 10 & Belmount School \\
\hline 11 & MIT University Meghalaya \\
\hline 12 & International School of Design \\
\hline 13 & Sunshine kids school \\
\hline 14 & Auxilian Girls High School \\
\hline 15 & Nongthymmai Government LP School \\
\hline 16 & DinetManikSyiem School \\
\hline 17 & National Institute of Technology \\
\hline 18 & Nongthymmai Nepali Higher Secondary School \\
\hline 19 & DapliehEducare \\
\hline 20 & Sunny Dale Higher Secondary School \\
\hline
\end{tabular}

Source: Collected through Primary Survey.

\section{Suggestive Measures to Prevent Congestion}

The measures to prevent traffic congestion can be classified into demand side measures as well as supply side measures. Some of the supply side measures include better road network and infrastructure, building of more flyovers, availability of public transportation, implementation of institutional buses and vehicles. Institutional measures include strict action against illegal parking, proper traffic management, car pooling arrangement, engagement of traffic personnel and technology etc. Demand side measurements would be controlling demand for use of personal cars in peak hours by peak-load pricing or congestion pricing (differential tax), reduction in public transport fares, which may reduce public revenue but overall social benefit from less required traffic personnel, less road, fuel use and pollution etc.

Respondents have been asked to reveal a number of valuable suggestions which is analysed by assigning codes to each of the suggestions. The results of the frequency of suggestions provided by all the respondents have been listed in Table 3. 


\section{Table 3}

Frequency Distribution of Remedial Measures for Traffic Congestion and their Ranks Respectively for Private Vehicle Owners/Commuters, Taxi Drivers and Businessmen

\begin{tabular}{|c|c|c|c|c|c|c|c|}
\hline \multirow[b]{2}{*}{ S1. } & \multirow[b]{2}{*}{ Suggestions } & \multicolumn{2}{|c|}{$\begin{array}{c}\text { Private Vehicle Owners } \\
\text { and Commuters }\end{array}$} & \multicolumn{2}{|c|}{ Taxi Drivers } & \multicolumn{2}{|c|}{ Businessmen } \\
\hline & & Frequency & Rank & \begin{tabular}{|l|} 
Frequency \\
\end{tabular} & Rank & Frequency & Rank \\
\hline 1 & Better road network & 8 & 10 & 8 & 7 & 7 & 10 \\
\hline 2 & $\begin{array}{l}\text { Proper location of schools and } \\
\text { offices, widening of roads and } \\
\text { public transport }\end{array}$ & 26 & 2 & 31 & 2 & 23 & 3 \\
\hline 3 & $\begin{array}{l}\text { Expansion of road, better road } \\
\text { infrastructure }\end{array}$ & 16 & 6 & 28 & 3 & 16 & 5 \\
\hline 4 & Build flyovers & 17 & 5 & 9 & 6 & 11 & 8 \\
\hline 5 & $\begin{array}{l}\text { Shifting of institutions and } \\
\text { government offices in the outskirts } \\
\text { of the city }\end{array}$ & 1 & 14 & 1 & 11 & 2 & 13 \\
\hline 6 & $\begin{array}{l}\text { Expansion of road and building of } \\
\text { flyovers }\end{array}$ & 13 & 7 & 53 & 1 & 13 & 7 \\
\hline 7 & $\begin{array}{l}\text { Construction of } 4 \text {-Lane, flyovers } \\
\text { and discourage road side parking }\end{array}$ & 11 & 8 & 23 & 4 & 20 & 4 \\
\hline 8 & Construction of more bypass road & 2 & 13 & 1 & 11 & 5 & 11 \\
\hline 9 & Well Planned city & 3 & 12 & 1 & 11 & 4 & 12 \\
\hline 10 & $\begin{array}{l}\text { Expansion of road, better road } \\
\text { infrastructure by construction of } \\
\text { more bypass }\end{array}$ & 1 & 14 & 1 & & 2 & 13 \\
\hline 11 & $\begin{array}{l}\text { Proper Traffic Management } \\
\text { and strict penalty for overtaking } \\
\text { vehicles within the city }\end{array}$ & 25 & 3 & 8 & 7 & 30 & 1 \\
\hline 12 & Strict penalty for illegal parking & 30 & 1 & 2 & 10 & 14 & 6 \\
\hline 13 & $\begin{array}{l}\text { Implementation of institutional } \\
\text { buses so as to reduce concentration } \\
\text { of private vehicle on city road and } \\
\text { carpooling }\end{array}$ & 10 & 9 & 13 & 5 & 11 & 8 \\
\hline 14 & $\begin{array}{l}\text { Traffic diversion from highly } \\
\text { congested roads to the } \\
\text { underutilised roads }\end{array}$ & 8 & 10 & 7 & 8 & 10 & 9 \\
\hline 15 & $\begin{array}{l}\text { ITS and tracking congestion } \\
\text { through android cell phones }\end{array}$ & 22 & 4 & 8 & 7 & 25 & 2 \\
\hline 16 & $\begin{array}{l}\text { Strict traffic rules, implementation } \\
\text { of awareness programme }\end{array}$ & 7 & 11 & 6 & 9 & 7 & 10 \\
\hline & Total & 200 & & 200 & & 200 & \\
\hline
\end{tabular}

Source: Calculated by the author using the primary data collected.

Majority of the respondents have suggested for the imposition of strict penalty for illegal parking and for overtaking of vehicles within the city, proper traffic management and plan for appropriate location of schools and offices, widening of roads wherever possible and increasing use of public transport, construction of 4-Lane, flyovers and discourage road side parking, expansion of road wherever feasible, better road infrastructure, ITS and tracking of congestion through GPS system in order to control traffic congestion in Shillong (Table 3). 


\section{Conclusion}

This paper tried to study the nature of traffic flow in Shillong city. It also tried to analyse the impact of locational distribution on traffic congestion. Results showed that flow of traffic is concentrated in locations with highest number of institutions surrounding it. Also the result of Chi-square test supports the alternative hypothesis. It showed that the calculated value is greater than the critical value in all cases and therefore, implies that, locational misdistribution of government offices and institutions across these chosen points causes variation in occurrence of traffic congestion.

Measures to reduce traffic congestion have also been examined. Majority of the respondents have suggested for institutional measures like, imposition of strict penalty for illegal parking and for overtaking vehicles within the city, proper traffic management and plan for appropriate location of schools and offices, and application of supply side measures like widening of roads, construction of 4-Lane wherever possible, flyovers and discourage road side parking, expansion of road, better road infrastructure, etc. Also, relocation of offices and other institutions towards outskirt with improved connectivity and shifting of residential quarters in newly relocated respective institutions can be an important non-technological policy option to divert congestion sustainably.

Analysis of the nature of traffic congestion in the city Shillong gives rise to the following policy recommendations:

1. Steps should be taken so that institutions are reallocated along with the residence, to the city outskirts, to divert the traffic towards less congested locations so as to reduce concentration of institutions only at a particular area;

2. Steps should be taken so that institutions provide bus facilities to their employees and students, to reduce pressure of vehicles on the roads. Also, public masstransportation system may be improved to reduce number of vehicles on road at any time;

3. Proper parking facilities should also be provided in order to prevent stoppage of cars anywhere on the roadside and regulate it.

\section{References:}

Chama, N. C. C. 2013. Investigating the contributory factors to traffic congestion in Nairobi City, Kenya International Journal of Science and Research 4(5): 32533256.

Gupta, S. P. 2000. Statistical Methods. Sultan Chand and Sons. New Delhi. 954 p.

He, S. 2012. Analysis Method of traffic congestion degree based on spatio-temporal simulation, International Journal of Advanced Computer Science and Applications 3(4): 12-17.

Jain, V.; Sharma, A.; Subramanian, L. 2012. Road traffic congestion in the developing world. In Proceedings of the $2^{\text {nd }}$ ACM Symposium on Computing for Development, 1-10.

Khan, T.; Islam, M. R. 2013. Estimating costs of traffic congestion in Dhaka city, International Journal of Engineering Science and Innovative Technology 2(3): 281-289.

Mahmud, K.; Gope, K.; Chowdhury, S. M. R. 2012. Possible causes and solutions of traffic jam and their impact on the economy of Dhaka City, Journal of Management and Sustainability 2(2): 112-135. 
Olawale, O.; Oyedele, L.; Owolabi, H.; Kusimo, H.; Gbadamosi, A.; Akinosho, T.; Kadiri, K. 2019. Complexities of smart city project success: A study of real-life case studies. In Proceedings of the CIB World Building Congress 2019, 17 - 21 June, Hong Kong SAR, China. 10 p.

Raheem, S. B.; Olawoore, W. A.; Olagunju, D. P.; Adeokun, E. M. 2015. The cause, effect and possible solution to traffic congestion on Nigeria road (A Case Study of Basorun - Akobo Road, Oyo State), International Journal of Engineering Science Invention 4(9): 10-14.

Uddin, A. 2009. Traffic congestion in Indian Cities: Challenges of a Rising Power. Kyoto of the Cities, Smart Cities in the Post-Crisis Era, 26-28 March, Naples, Italy. 7 p.
Ukpata, J. O.; Etika, A. A. 2012. Traffic congestion in major cities of Nigeria, International Journal of Engineering and Technology 2(8): 1433-1438.

Mappery. 2019. Available from Internet: <http://www. mappery.com/Shillong-City-Map $>$. Accessed: $20^{\text {th }}$ April 2019.

Ye, S. 2012. Research on urban road traffic congestion charging based on sustainable development, Physics Procedia 24: 1567-1572.

\section{jitte 448}

